\title{
PIETAS DAN CARITAS: \\ PELAYANAN DIAKONIA SEBAGAI SUATU \\ IMPLEMENTASI KEPEDULIAN SOSIAL GEREJA \\ UNTUK MENOLONG MERETAS ANGKA KEMISKINAN \\ DI INDONESIA
}

\author{
Mariani Febriana
}

\begin{abstract}
ABSTRAKSI
Meningkatnya angka kemiskinan di Indonesia hari ini menjadi suatu tamparan keras bukan hanya bagi pemerintah, melainkan juga bagi gereja. Meskipun harus diakui bahwa penyebab dari kemiskinan ini disebabkan dari beberapa faktor dan diantaranya adalah faktor alam, namun tidak bisa tidak ada hal-hal yang justru disebabkan oleh faktor manusia. Usaha telah dilakukan oleh pemerintah untuk meretas persoalan ini, namun betapapun usaha besar yang sudah dilakukan oleh pemerintah, namun tetap tidak bisa tidak tanggung jawab semua unsur komponen bangsa untuk bekerjasama dengan pemerintah tidak bisa dilepaskan dalam mengatasi persoalan ini dan justru diantara komponen bangsa itu adalah orang percaya.
\end{abstract}

Komitmen orang percaya untuk melibatkan diri dalam usaha membangun kemanusiaan sebenarnya bukanlah suatu usaha yang baru. Dalam perjalanan Sejarah, Gereja sudah membutkikan dengan setia untuk mengkomitkan dirinya kepada tugas panggilan ini. Teologi gereja yang bertitik tolak dari Kitab Suci sudah memberikan arahan kepada gereja, bagaimana seharusnya gereja menyatakan kehadirannya dalam kehidupan. Pietas dan caritas merupakan jantung penting dalam mewujudkan kehadiran dan peran aksi gereja dalam kehidupan. Pietas dan caritas bukanlah suatu slogan kosong dalam hidup gereja, namun disitulah gereja membuktikan kepada dunia tentang kehadiran dan panggilan dirinya.

Pietas dan caritas adalah suatu kenyataan hidup beribadah yang dibawa dalam realita sosial. Ibadah orang percaya kepada 
Allah nyata dalam tindakan konkretnya kepada sesama. Tindakan konkret ini bukan hanya sekedar pelayanan kasih yang ekslusif dalam jemaat, melainkan suatu pelayanan gereja yang inkslusif yang diwujudkan dalam tindakan-tindakan keadilan, khususnya menolong orang miskin yang ada disekitarnya. Tindakan pelayanan keadilan itu dapat berupa tindakan preventif, kuratif, reformatif ataupun transformatif. Pelayanan ini adalah panggilan Allah kepada gereja untuk membangun perdamaian dan persaudaraan dengan sesama manusia, mewujudkan keadilan sosial dan perwujudan Kerajaan Allah, serta suatu upaya membangun kemanusiaan dan kesejahteraan bagi semua.

Kata Kunci: Pietas, caritas, diakonia, leitourgia, keadilan, kuratif, preventif, transformatif, panggilan Allah, persaudaraan sejati dan kesejahteraan bagi sesama

\section{PENDAHULUAN}

Data Badan Pusat Statistik Nasional pada tahun 2013 menyebutkan bahwa angka kemiskinan di Indonesia per September 2013 tercatat 28,55 juta orang atau 11,47 persen dari jumlah penduduk Indonesia. Sebelumnya pada Maret 2013 angka kemiskinan tercatat 28,07 juta orang. Jadi menurut data ini dapat dikatakan bahwa angka pertumbuhan penduduk miskin di Indonesia bertambah menjadi sebanyak 480 ribu orang miskin. Karena itu Menko Kesra menargetkan angka kemiskinan berkurang menjadi 8 hingga 10 persen, diakhir tahun 2014, meskipun disadari bahwa usaha ini bukanlah suatu usaha yang mudah. Ketidakmudahan ini disebabkan karena kenaikan jumlah penduduk miskin di Indonesia justru karena akibat dari adanya inflasi yg tinggi sebesar 5.02 persen, yang merupakan merupakan imbas dari kenaikan harga BBM pada bulan Juni 2013, kenaikan harga beras, dan akibat bencana yang terjadi secara beruntun di Indonesia. ${ }^{1}$

\footnotetext{
${ }^{1}$ Menko Kesra Akui Sulit Tekan Angka Kemiskinan, diakses dari http://www.menkokesra.go.id/content/menko-kesra-kemiskinan-masih-menjadi-prtahun-2014). Bandingkan juga Margareta Engge Kharismawati, Penurunan Angka Kemiskinan di 2014 Sulit Tercapai, diakses dari http://nasional.kontan.co.id/news/penurunan-angka-kemiskinan-di-2014-sulittercapai.
} 
Usaha meretas persoalan ini sebenarnya harus diakui memang bukan hanya sekedar mengandalkan program nasional meretas kemiskinan, melainkan juga harus diimbangi dengan pembangunan akses infrastruktur ke desa, guna pendayagunaan yang maksimal dari amsyarakat di desa. Di sisi lain, usaha meretas persoalan ini juga menjadi tanggung jawab dari gereja dan bukan hanya sekedar menaruh beban ini dipunggung pemerintah. Dikatakan menjadi tanggung jawab gereja karena pelayanan kepada sesama berkawan akrab dengan ibadah kepada Allah. Hidup gereja dari Senin hingga Sabtu merupakan ungkapan dari kehidupan doanya yang dituntun oleh firman dan aplikasi dari firman serta partisipasi dia dalam sakramen pada ibadah pujian pada hari Minggu. ${ }^{2}$ Pelayanan kepada sesama merupakan suatu implementasi dari hidup ibadah gereja, yang tidak terbatas kepada orang percaya melainkan juga kepada dunia disekitarnya. Artinya, tindakan pietas kepada Allah yang bersifat personal dan komunal dalam gereja selalu berujung kepada caritas, yang tercakup dalam relasi sosial. Karena itu tidak dapat tidak dikatakan bahwa setiap orang percaya dan setiap organisasi gereja sudah seharusnya terlibat dalam kehidupan masyarakat dan usaha meretas persoalan-persoalan sosial yang ada disekitarnya.

Niebuhr mengajukan kritik terhadap tanggung jawab sosial gereja yang ogah-ogahan ini sebagai suatu semangat Isolationisme. Semangat ini justru bagi Niebuhr merupakan suatu bidat yang mungkin tidak disadari oleh gereja. Isolationisme tampil kala gereja memberikan respon kepada Allah, namun hanya bertindak bagi dirinya sendiri. Gereja yang terisolir ini menolak klaim tanggung jawab dalam fungsi sosial dirinya dalam masyarakat dan meninggalkan masyarakat sekular itu berjuang dalam dirinya sendiri. ${ }^{3}$

Di sisi lain, dalam diskusinya mengenai Teologi Ketidakadilan Sosial dari John Calvin, Wolterstorff menegaskan bahwa sikap gereja yang gagal untuk memenuhi tuntutan keadilan dan kasih kepada sesamanya manusia merupakan suatu kegagalan dari gereja melaksanakan keterkaitan kemanusiaannya dengan sesama

\footnotetext{
${ }^{2}$ Elsie Anne McKee, Diakonia in the Classical Reformed Tradition and Today, (Grand Rapids: Wm B Eerdmans, 1989), 33.

${ }^{3}$ H. Richard Niebuhr, The Responsibility of the Church for Society, diakses dari http://www.religion-online.org/showarticle.asp?title=2731.
} 
yang lain, yang merupakan ikon Allah, dan karena itu tindakan ini disebut sebagai "the greatest inhumanity," suatu tindakan terbesar dari ketidakberperikemanusiaannya gereja terhadap persoalanpersoalan publik. Bagi Niebuhr, Agama Protestan macam ini sudah menjadi demikian spiritualistik dan individualistik sehingga kehidupan konkret dari masyarakar sekular ditolak sebagai melampaui dari skup tanggung jawab rohani gereja.

Sikap penolakan gereja diatas disebabkan karena beberapa alasan, diantaranya yaitu:

1. Adanya sikap reaktif yang berlebihan dari gereja terhadap Teologi Liberal yang mengidentifikasikan pesan kristiani dengan suatu panggilan terhadap reformasi sosial. Memang tidak ada injil sosial, namun konfrontasi Allah terhadap orang berdosa secara pribadi juga memiliki dampak sosial. Karena itu tanggung jawab sosial gereja dalam hal ini tidak dapat diabaikan.

2. Adanya suatu pembacaan yang pesimistik terhadap II Timotius 3:13 menyebabkan orang percaya merasa bahwa setiap usaha membangun kehidupan piblik bersama justru akan berujung kepada keadaan yang tidak semakin baik melainkan buruk. Karena itu tidak ada alasan yang cukup signifikan bagi orang percaya untuk melakukan sesuatu yang berkaitan dengan problema sosial selain menyelamatkan jiwa melalui penginjilan pribadi.

3. Adanya pemikiran yang timbul di kalangan Injili mengenai perbedaan yang tajam antara urusan di dalam dan di luar gereja, di mana urusan gereja adalah hal-hal rohani, sedangkan urusan di luar gereja adalah hal-hal yang bersifat sosial. Karena urusan gereja adalah rohani, dan karena itu gereja tidak pantas berkutat dalam urusan sosial di luar gereja.

4. Individualisme dalam gereja menyebabkan sikap acuh tak acuh gereja dari kepedulian sosial. Sikap ini lahir karena gereja hanya melihat kebutuhan dirinya sendiri secara eksklusif dalam

\footnotetext{
${ }^{4}$ Nicholas Wolterstorff, Hearing the Call: Liturgy, Justice, Church and World, (Grand Rapids: WmB Eerdmans, 2011), 127.
} 
konteks penekanan ajaran persekutuan orang kudus dan melupakan pelayanan kasih dari gereja.

5. Adanya suatu pendapat yang berkembang dalam gereja bahwa politik itu kotor, karena tindakan sosial bisa jadi berdekatan dengan aktivitas politik, maka banyak gereja berdiri berjauhan dengan tindakan kepedulian sosial gereja.

Karena itu sikap gereja yang tidak tanggap dengan persoalan sosial di sekitar mereka, di antaranya kemiskinan, menurut Moberg adalah merupakan suatu tanda dari kematian rohani gereja. Kurangnya kepedulian gereja terhadap kebutuhan sosial sesama adalah merupakan persoalan rohani dari gereja, Karena itu, jikalau gereja mengalami perjumpaan sejati dengan Allah, maka hidupnya diubah dari gratifikasi diri kepada kepedulian sosial, suatu kepedulian kepada sesama.

\section{MEMAHAMI DIAKONIA \\ SEBAGAI SUATU PELAYANAN KEPEDULIAN GEREJA SECARA SOSIAL}

\section{Pemahaman Makna Kitab Suci Mengenai Kepedulian Sosial Gereja Terhadap Orang Miskin}

Kepedulian gereja terhadap orang miskin didasarkan pada penyelamatan Allah kepada manusia berdosa. Dalam catatan Perjanjian Lama, Bangsa Israel mengenal Allah sebagai Allah yang membebaskan mereka dari perbudakan di Mesir. Di bawah kepemimpinan Musa, bangsa yang tertindas ini memperoleh kembali kemerdekaan mereka. Karena kuasa Allah yang sudah membebaskan mereka, maka Allah memerintahkan umat-Nya untuk menyatakan keadilan-Nya, yaitu perhatian khusus kepada orang-orang yang lemah dan miskin, yaitu orang-orang yang tidak memiliki sumber-sumber yang menjadi kebutuhannya dalam hidup dan tidak mudah bagi mereka untuk meraih itu. ${ }^{6}$ Dalam hal ini, Allah sangat membela orang-orang yang miskin dan lemah itu dan mengingatkan Israel untuk menolong orang-orang ini,

\footnotetext{
${ }^{5}$ David O. Moberg, Inasmuch: Christian Social Responsibility in 20th Century America, (Grand Rapids: WmB Eerdmans, 1973), 20-22.

${ }^{6}$ Thomas C. Oden, Pastoral theology: Essentials of Ministry, (New York: Harper and Row Pub, 1983), 268.
} 
sebagaimana Israel diingatkan bagaimana keadaan mereka dahulu, yang dihadapan Allah sebenarnya mereka tidak memiliki sesuatu, namun karena kemurahan Allah, mereka dapat menerima apa yang ada pada mereka. (Bandingkan Ulangan 10:17-19; 24:17-22; 26;11; Im. 19:33,34; Maz. 103:6). ${ }^{7}$

Allah sangat memperhatikan orang miskin di tengah umatNya. Orang miskin dalam hal ini bukanlah karena mereka adalah kelas masyarakat tertentu, melainkan orang miskin disini adalah orang yang tidak mempunyai penolong. Sikap Allah ini menjadi dasar dari sikap gereja terhadap orang miskin sebagai perwujudan dari solidaritas gereja secara nyata sebagai umat Allah. Praktek tahun Sabat dan tahun Yobel (Ulangan 15 dan Imamat 25) mengajarkan bahwa orang miskin seharusnya dibukakan jalan agar tidak tenggelam semakin dalam di dalam lumpur hutang dan kemiskinan. Gereja yang membiarkan praktek-praktek pemiskinan dengan permainan bebas kekuatan dan praktek-praktek kuasa ekonomi sama dengan menciderai maksud-maksud Torah.

Dalam Perjanjian Baru, perjamuan kudus dan diakonia itu merupakan suatu ikatan yang tidak terpisahkan, berkaitan dengan keikutsertaan kita pada jalan yang telah dijalani oleh Yesus Kristus. Dalam I Korintus 11:27,29, Paulus mengecam egoisme yang rakus dan individualisme tanpa kasih dalam pelaksanaan makan dan minum yang tidak layak. Dalam konteks ini maka cara hidup seperti ini menciderai tubuh Kristus, yang dalam hal ini jemaat Kristus itu sendiri. Teguran Paulus yang keras ini menyatakan bahwa tidak mungkin merayakan perjamuan kudus dengan benar apabila pada saat yang sama kita tidak memperhatikan dan tidak memperhitungkan mereka yang miskin dan lemah. Hal ini akan membangkitkan murka Allah dalam hidup kita. ${ }^{8}$

Pemahaman konsep di atas menolong kita melihat bahwa pelayanan diakonia gereja itu merupakan suatu analogi dari kemurahan Allah terhadap kita. Gereja dipanggil untuk melakukan

\footnotetext{
${ }^{7}$ Malcolm Brownlee, Tugas Manusia dalam Dunia Milik Tuhan: Dasar Teologis Bagi Pekerjaan Orang Kristen Dalam Masyarakat, (Jakarta: BPK Gunung Mulia, 1987), 67.

${ }^{8}$ A. Noordegraaf, Teologi dalam Perspektif Reformasi: Orientasi Diakonia Gereja, (Jakarta: BPK Gunung Mulia, 2011), 57.
} 
tindakan kasih yang sama kepada sesama yang menderita. ${ }^{9}$ Perhatian dan kepedulian gereja terhadap orang miskin bukan hanya tugas dari para pejabat gereja saja, melainkan menjadi tugas bagi semua orang percaya. Meskipun demikian, karena semua orang percaya terlibat masuk dalam tugas misi yang kompleks ini, maka dibutuhkan energi khusus dan arah dari para pelayan dalam gereja. Itulah sebabnya tugas pelayanan ini sejak mulanya sudah diatur oleh gereja. (Band. Kis. 6:1; Gal. 2:10; I Tim. 5: 3-16; Yak. 1:27).

\section{Pemahaman Makna Secara Teologis}

Di atas sudah dikatakan bahwa lemahnya pengajaran pelayanan sosial gereja dan hanya menekankan pengajaran persekutuan orang kudus menyebabkan gagalnya gereja berperan aktif dalam persoalan-persoalan sosial di luar gereja. Diakonia adalah salah satu aspek dari pelayanan kesaksian gereja, bahkan diakonia dipandang sangat penting dalam mendekatkan teologi dengan realitas manusia agar teologi gereja dapat selalu berdekatan dengan manusia dalam kenyataan yang konkret dan bukan sekedar suatu teologi diangan-angan. Karena itu keutuhan pelayanan dari gereja bertemu diantara firman dan perbuatan, khususnya dalam pelayanan diakonia gereja. ${ }^{10}$

Pemahaman kita tentang diakonia tidak dapat dipisahkan seperti disebutkan diatas diantara pietas dan caritas. Pietas dalam disiplin Calvinistik dipahami sebagai suatu sikap dan tindakan yang diarahkan kepada penyembahan dan pelayanan kepada Allah. Pietas juga dikaitkan dengan penghormatan dan kasih kepada pembawa gambar Allah. Dalam hal ini pietas adalah ethos dan tindakan dari umat yang percaya dan sekaligus sebagai suatu pengakuan kokoh untuk memperkenalkan Allah kepada pembawa gambar Allah dan menjadikan hidup mereka dibumi sebagai bagian yang memberikan pertolongan sebisa mungkin bagi pembawa gambar Allah. ${ }^{11}$

\footnotetext{
9 Thomas C. Oden, Pastoral theology: Essentials of Ministry, 268.

${ }^{10}$ Noordegraaf, Teologi dalam Perspektif Reformasi: Orientasi Diakonia Gereja, 16.

${ }^{11}$ Elsie Anne McKee, ed., John Calvin: Writings on Pastoral Piety, (New York: Paulist Press, 2001), 4-5.
} 
Sementara caritas, yang merupakan pelayanan yang diberikan atas nama Kristus memiliki arti yang luas. Caritas bukan hanya sekedar suatu pelayanan kasih semata, melainkan caritas juga adalah suatu pelayanan diakonal yang berkeadilan dari gereja. Pelayanan kasih dan keadilan ini bersifat preventif dan kuratif, mencegah dan menyembuhkan. Secara negatif, pelayanan ini memerangi dan jika mungkin mengatasi penderitaan, ketidak adilan, kemiskinan, kekurangmampuan dan secara positif meningkatkan kemungkinan-kemungkinan hidup dalam terang Injil. Dalam hal ini maka diakonia merupakan tugas perawatan kepada jemaat lokal, dan jemaat universal dan sekaligus juga bantuan kepada semua orang yang membutuhkan, khususnya mereka yang ada dalam kesusahan, yang miskin, para pengungsi, tahanan, pecandu obat dan korban bencana alam. ${ }^{12}$

Dalam konteks pemahaman diatas maka diakonia tersebut bukan hanya ditujukan kepada komunitas beriman dalam gereja, melainkan juga meluas kepada para pembawa gambar Allah. Itulah sebabnya pietas dalam arti khusus yang ditampilkan dalam ibadah di gereja memiliki relevansi diakonal dan kemasyarakatan. Banyak kali kita salah memahami pengertian Paulus dalam Galatia 6:10, sehingga kita hanya melihat kalangan sendiri dan tidak dapat melihat orang lain yang juga membutuhkan bantuan. Kita terjebak dalam sikap mengutamakan sesama rekan seiman, dan pincang dalam tindakan keadilan bagi sesama yang sangat membutuhkan. Ketika Paulus menghimbau berbuat baik kepada semua orang terutama kepada rekan seiman justru Paulus sedang mengingatkan gereja agar kesungguhan jemaat untuk membantu dapat dipercayai oleh dunia luar karena memang praktek hidup seperti ini sudah menjadi jantung dari hidup gereja. Bantuan yang diberikan oleh gereja dapat dipercaya oleh orang diluar jikalau di dalam hidupnya sendiri gereja sudah hidup dalam persaudaraan yang sejati. Dengan kata lain, berbuat baik kepada semua orang itu harus dimulai dari cara hidup gereja yang memang hidup dalam keadaan demikian, dan bukan sebagai suatu manipulasi perbuatan baik kepada sesama.

\footnotetext{
9.

Noordegraaf, Teologi dalam Perspektif Reformasi: Orientasi Diakonia Gereja, 8-
} 
Berdasarkan pemahaman yang luas di atas bahwa diakonia bukan hanya sekedar pelayanan kasih melainkan juga pelayanan keadilan. Itulah sebabnya sangat penting melihat arti kedua ini dalam kaitan dengan tanggung jawab gereja dalam kehidupan masyarat secara luas. Dengan perkataan lain, arti kedua ini menolong gereja menyatakan kepedulian mereka secara sosial dalam kehidupan masyarakat. Perlu diingat juga bahwa pelayanan gereja yang khas ini berkaitan erat dengan pemberitaan firman Allah dan pelaksanaan sakramen dalam gereja. Paradigma diakonia dan leitourgia disini merupakan suatu ajaran yang jelas dari gereja Reformed. Namun sayang paradigma ini yang bersumber dari Kisah 2;42 perlahan-lahan terlupakan dalam gereja. Elemen koinonia-caritas ini terlupakan karena adanya kecenderungan gereja justru memisahkan empat hukum pertama kepada Allah (Ibadah Minggu, Firman, Sakramen dan doa) dari enam hukum kedua kepada sesama (perhatian kepada sesama yaitu dengan memberi persembahan atau bantuan). ${ }^{13}$

Sidang Dewan Gereja Dunia yang dilakukan di Colombo, Sri Lanka pada tanggal 2-6 Juni 2012 yang lalu mengambil tema yang khusus, yaitu Perspektif Teologi Diakonia pada Abad ke-21. Diskusi dari tema ini difokuskan kepada isu mengenai keadilan dan diakonia, komunitas yang benar dan inklusif serta misi serta program penginjilan. Keputusan diskusi ini digagas dalam empat bagian, yaitu gereja, misi dan diakonia; diakonia kepada masyarakat yang termarjinalkan; diakonia untuk transformasi dan tantangan dan kesempatan. Yang menarik dalam diskusi ini adalah diakonia untuk transformasi. Secara teologis, teologia untuk transformasi ini menjadi suatu sasaran penting dalam pola kepedulian gereja hari ini. Bahkan teologia yang bersifat transformatif inilah yang menjadi pergumulan gereja dalam perjalanannya hingga hari ini. Diakonia yang transformatif ini adalah suatu perayaan kehidupan, suatu pelayanan yang membuat perayaan kehidupan ini dimungkinkan bagi semua orang. Diakonia macam begini akan berani menembus sistem yang menyalahgunakan kekuasaan dan menolak keadilan kepada orang miskin. Dalam diakonia ini, gereja bersaksi mengenai tujuan Allah dan berpartisipasi dalam misi Allah.

${ }^{13}$ Elsie Anne McKee, Diakonia in the Classical Reformed Tradition and Today, 33. 
Diakonia transformatif ini juga sangat menantang karena bersifat menghibur dan bersifat melakukan konfrontasi. Tanpa karya yang bersifat transformatif ini, maka wajah diakonia itu hanya sekedar pelayanan, yang secara samar melayani kepentingan dari yang tertindas dan kuasa yang tereksploitasi dengan menutupi keterlibatan mereka. Jikalau diakonia yang berkaitan dengan keadilan ini berhenti menantang ketidakadilan dan kuasa yang disalahgunakan maka diakonia tersebut bukan lagi menjadi diakonia yang otentik. Diakonia disisi lain merupakan suatu tindakan kreatif yang diberdayakan oleh Roh Kudus, di mana tindakan kreatif dari diakonia akan membawa dunia kepada apa yang Allah kehendaki. ${ }^{14}$

Pelayanan diakonia adalah suatu pelayanan yang bersifat imperatif, karena tugas pelayanan ini diberikan oleh Raja Gereja kepada kita. Di dalam namaNya, gereja dipanggil untuk menjadi tanda pertolongan dan keselamatan terhadap semua mereka yang tidak mempunyai pertolongan dan melalui tindakan ini gereja menjadi saksi dari kasih Allah kepada yang miskin dan yang menderita. Dalam hal inilah tersimpul erat suatu hubungan yang tidak terpisahkan antara diakonia dan leitourgia. Di antara pietas dan caritas. Berkaitan dengan diskusi dalam artikel ini, maka orang miskin dan yang menderita ini menjadi sorotan utama dari kepedulian gereja secara sosial.

\section{GEREJA DAN REALITA KEMISKINAN DALAM MASYARAKAT}

Realitas kemiskinan dalam negara yang sudah dipaparkan pada bagian pendahuluan sebenarnya menjadi suatu tamparan keras bagi pelayanan gereja di Indonesia. Forbes mengatakan bahwa krisis dalam masyarakat sebenarnya juga merupakan bagian dari krisis dalam gereja juga. Krisis dari kemiskinan ini tanpa disadari menimbulkan multiplikasi krisis dalam masyarakat, diantaranya akibat dari krisis ini berakibat kepada resiko kematian atau kurang gizi yang sangat tinggi bagi ibu hamil, ibu menyusui,

\footnotetext{
${ }^{14}$ World Council of Churches, Theological Perspectives on Diakonia in 21st Century, (Colombo, 2012), diakses dari http://www.oikoumene.org/en/resources/documents/wcc-programmes/unitymission-evangelism-and-spirituality/just-and-inclusive-communities/theologicalperspectives-on-diakonia-in-21st-century
} 
bayi, balita, dan lanjut usia. Asupan gizi yang rendah bagi anakanak, pemeliharaan kesehatan yang kurang, apalagi didukung oleh lingkungan hidup yang buruk, dan biaya untuk berobat tidak ada semakin memperparah efek dari kemiskinan ini.

Kemiskinan ini juga benar-benar sudah menghancurkan citacita masyarakat Indonesia khususnya para generasi muda. Masih banyak penduduk Indonesia karena keterbatasan ekonomi yang tidak mendukung menyebabkan banyak anak yang putus sekolah karena menunggak SPP, siswa SD yang nekat bunuh diri karena malu sering ditagih oleh pihak sekolah, atau anak di bawah umur bekerja keras dengan tujuan memberi sesuap nasi untuk keluarganya.

Dengan dampak krisis yang ada yang disebabkan oleh karena faktor kemiskinan, dan ujung-ujungnya gereja juga dan masyarakat secara luas yang mengalami dampak dari hal ini, maka jalan yang harus ditempuh juga oleh gereja adalah menyatakan kepeduliannya terhadap persoalan ini. Kemiskinan yang tidak teratasi ini justru akan berdampak masif karena kemiskinan juga dapat meningkatkan tindakan kriminalitas dan angka pengangguran. Dengan tingginya angka kemiskinan di Indonesia, maka hal ini menjadi masalah tersendiri bagi negara ini dan sampai saat ini solusi yang sudah diberikan pemerintah belum dapat menutupi angka kemiskinan yang ada. Dalam kondisi krisis seperti ini justru bagi Forbes merupakan suatu kesempatan besar bagi gereja. Krisis ini menghadirkan suatu kesempatan yang luar biasa bagi gereja untuk melakukan tugasnya yang lebih besar. $^{15}$ Jadi berkaitan dengan realita tersebut maka suatu kesempatan besar terbuka luas bagi gereja hari ini dalam melakukan pelayanan keadilannya. Secara umum memang Negara telah melakukan upaya maksimal dalam meretas kemiskinan. Namun tidak bisa tidak berkaitan dengan pangilan hakiki gereja, maka gereja bertanggung jawab juga melakukan misi Allah hari ini dengan memperkenalkan Allah melalui tindakannya yang konkret, melalui kepedulian sosial.

\footnotetext{
15 James A Forbes Jr, "The Stake of the Church in Social Movement," Christianity and the Social Crisis in the 21 Century, ed. by Paul Raushenbush, (Harper Collins e-books), 267-268.
} 
Berkaitan dengan usaha gereja meretas kemiskinan ini juga sejalan dengan keputusan yang disarankan oleh Martin Bucer di Straszburg. Bagi Bucer, gereja harus saling membantu dalam mengatasi kemiskinan dalam suatu wilayah. Pada tahun 1523 pemeliharaan orang miskin masih diurus oleh negara, karena pada waktu itu tugas diaken masih berkutat pada pelayanan pastoral membantu para pemberita firman. Dalam hal ini Bucer tidak puas karena dia menginginkan agar pelayanan pastoral ini berkaitan dengan orang miskin, yang menurutnya juga menjadi tanggung jawab gereja. ${ }^{16}$ Pelayanan gereja terhadap orang miskin ini dikonkritkan olehnya berdasarkan realita zaman pada waktu itu, khususnya banyak gadis yang tidak dapat menikah pada waktu itu karena miskin dan Bucer memberikan semacam 'mas kawin' untuk membantu mereka. Di samping itu ada banyak pemuda yang tidak dapat melanjutkan studi karena miskin, maka Bucer memberikan beasiswa kepada mereka.

Secara tradisional, pelayanan gereja terhadap orang miskin dilakukan pertama-tama dengan menyortir kembali jenis dari kemiskinan, agar usaha mengurangi angka kemiskinan ini dapat terlaksana dengan tepat sasaran. Sider menegaskan bahwa untuk mengurangi penderitaan dari orang miskin, maka sangat penting mengetahui apa yang menyebabkan kemiskinan tersebut. Jikalau kita hanya mengira bahwa kemiskinan itu disebabkan karena kemalasan, sementara pada faktanya sarana yang tidak memadai dan sistem yang tidak adil yang menjadi penyebab utamanya, maka usaha kita yang terbaik pun juga akan gagal. Jikalau kita mengira bahwa struktur yang tidak adil adalah penyebab satusatunya dari kemiskinan, sementara pada faktanya pilihan-pilihan pribadi memainkan peran yang utama, maka kita juga akan gagal. Karena itu agar kita dapat menolong orang miskin dengan tepat sasaran, maka kita harus mulai dari hal-hal yang bersifat realita, yang menyebabkan kmiskinan mereka. ${ }^{17}$ Usaha ini dapat dimulai dengan melakukan penelitian dari tingkatan kemiskinan ataupun jenis dari kemiskinan yang dialami dalam masyarakat. Thomas Aquinas, sebagaimana dikutip oleh Oden, dalam hal ini membantu kita melihat apa yang dimaksud dengan tingkatan kemiskinan

\footnotetext{
${ }^{16}$ J.L. Ch. Abineno, Diaken, Diakonia dan Diakonat Gereja, (Jakarta: BPK Gunung Mulia, 2008), 45-47.

${ }^{17}$ Ronals J. Sider, Rich hristians In An Age of Hunger: Moving from Affluence to Generosity, (Dallas: Word Publishing, 1997), 125.
} 
tersebut. Aquinas membedakan tiga macam tingkatan dari kemiskinan, yaitu: kemiskinan biasa, akut dan kemiskinan ekstrim. ${ }^{18}$

Kemiskinan yang paling banyak menyebar adalah kemiskinan biasa, di mana seseorang hanya dapat memenuhi batas minimal dari kebutuhan hidupnya, sedikit memiliki harta atau tidak memiliki harta. Mereka hidup hari demi hari pada standar hidup yang paling dasar, dimana mereka tidak dapat menyediakan bagi diri mereka sendiri makanan, pakaian dan tempat tinggal. Menurut Aquinas, pertolongan bagi tingkatan kemiskinan dalam level ini dibagi menjadi dua, yaitu: Pertolongan preventif, yaitu suatu tindakan yang akan mencegah seseorang terjerumus ke dalam kemiskinan akut atau ekstrim dan pertolongan kuratif yang akan menolong mengubah kondisi sosial lahiriah tresebut dan pola-pola psikologis dari dalam yang menguatkan mentalitas kemiskinan demikian.

Kemiskinan akut ditujukan kepada krisis di mana kondisi untuk mendukung kehidupan adalah bersifat sementara dan bahkan terancam. Jikalau hidup hendak berlanjut maka pertolongan yang bersifat eksternal dibutuhkan untuk mengatasi defisit yang ada. Pelayanan kepada orang miskin macam begini adalah bersifat darurat. Sedangkan kemiskinan ekstrim ditujukan kepada suatu kondisi yang berulang dan berlanjut dengan keadaan tanpa sarana untuk memperoleh kebutuhan hidup. Kemiskinan macam ini tidak memiliki daya di dalam dirinya sendiri untuk pulih. Karena itu perhatian terhadap kemiskinan macam ini diberikan dalam bentuk pereventif, kuratif dan pertolongan darurat.

Dalam konteks bahasa modern memahami tingkat dari kemiskinan diatas, menurut jenisnya, maka kemiskinan dibedakan menjadi kemiskinan absolut/mutlak, yaitu keadaan yang mana pendapatan kasar bulanan tidak mencukupi untuk membeli keperluan minimum sebuah isi rumah yang diukur berdasarkan tahap perbelanjaan minimum, dan kemiskinan relatif, yaitu suatu kemiskinan yang dilihat berdasarkan perbandingan antara sesuatu tingkat pendapatan lainnya. Sebagai contoh adalah seseorang yang tergolong kaya (mampu) pada masyarakat desa tertentu bisa jadi termiskin pada masyarakat desa yang lain.

18 Thomas C. Oden, Pastoral theology: Essentials of Ministry, 273. 
Berdasarkan penyebabnya, maka kemiskinan itu dapat digolongkan dalam tiga kategori, yaitu pertama kemiskinan struktural, kultural dan rasional. Kemiskinan struktural ditunjukkan dalam suatu kondisi di mana sekelompok orang berada di dalam wilayah kemiskinan, dan tidak ada peluang bagi mereka untuk keluar dari kemiskinan. Mereka terjebak dalam lingkaran setan kemiskinan, dan bisa dikatakan mengalami "kemiskinan abadi". Jika seorang pemulung punya anak, dan dia tidak memiliki biaya untuk memberikan gizi yang cukup, maka akan berdampak kepada kecerdasan sang anak, lalu juga tidak punya biaya menyekolahkan anaknya, maka seakan-akan keluar dari wilayah kemiskinan hanyalah sebuah angan-angan. Pencegahan terhadap persoalan ini dapat dilakukan dengan dua hal, yaitu pemberian gizi yang baik sejak masa balita dan pendidikan yang memadai. Dengan dua hal tersebut, kemiskinan struktural bisa diatasi perlahan-lahan. Program nasional atau gerakan masyarakat pemberian gizi tambahan untuk balita miskin, penyediaan sekolah yang gratis untuk masyarakat miskin, dan program anak asuh juga merupakan beberapa upaya penting dalam menanggulangi kemiskinan struktural ini.

Kemiskinan kultural terjadi karena budaya yang membuat orang miskin, atau dalam istilah antropologi Koentjaraningrat, kemiskinan ini disebabkan karena adanya mentalitas atau kebudayan kemiskinan. ${ }^{19}$ Tidak heran dalam hal ini, maka salah satu Capres/ Cawapres 2104 mengusung program revolusi mental untuk meretas mentalitas pemiskinan ini. Mentalitas masyarakat seperti ini cenderung pasrah dengan keadaannya dan menganggap bahwa mereka miskin karena turunan, atau karena dulu orang tuanya atau nenek moyangnya juga miskin, sehingga usahanya untuk maju menjadi kurang. Kemiskinan yang umum seperti ini yang menurut Aquinas justru banyak menyebar dan disinyalir juga kemiskinan macam beginilah yang tumbuh subur di negeri ini sehingga perlu adanya revolusi mental untuk mengatasi persoalan ini.

Selanjutnya kemiskinan rasional yang disebabkan oleh keterbatasan kualitas maupun kuantitas Sumber Daya Alam dan Sumber Daya Manusia. Tidak adanya/ hilangnya sumber-sumber

\footnotetext{
${ }^{19}$ Koentjaranigrat, Manusia dan Kebudayaan di Indonesia, (Jakarta: Djambatan, 1979), 380-386.
} 
yang menguntungkan dan kurangnya keahlian dan kualitas sumber daya manusianya menyebabkan terjadinya kemiskinan ini. Selain itu pula kemiskinan rasional bisa diakibatkan oleh musibah, bencana alam dan bencana-bencana lainnya, seperti tahun 2004 ketika terjadi tsunami di Aceh, yang mana banyak orang harus kehilangan harta benda mereka dan hidup dengan kekurangan, atau mungkin akibat yang sama yang dialami oleh korban amukan massa. Kemiskinan rasional juga dapat terjadi dalam konsep roda kehidupan, dimana ada saatnya seorang pemilik perusahaan yang jatuh miskin dikarenakan perusahaannya merugi, dan berubahnya seseorang yang kaya menjadi miskin karena sebab dan akibat yang masuk akal.

Dari bebeberapa pendekatan dapat disimpulkan bahwa yang disebut miskin dan kemiskinan itu paling tidak masuk dalam beberapa indikator, yaitu terbatasnya kecukupan dan mutu pangan; terbatasnya akses dan rendahnya mutu layanan kesehatan; terbatasnya akses dan rendahnya mutu layanan pendidikan; terbatasnya kesempatan kerja dan berusaha; lemahnya perlindungan terhadap aset usaha dan perbedaan upah; terbatasnya akses layanan perumahan dan sanitasi; terbatasnya akses terhadap air bersih; lemahnya kepastian kepemilikan dan penguasaan tanah; memburuknya kondisi lingkungan hidup dan sumberdaya alam, serta terbatasnya akses masyarakat terhadap sumber daya alam; lemahnya jaminan rasa aman; lemahnya partisipasi; besarnya beban kependudukan yang disebabkan oleh besarnya tanggungan keluarga; tata kelola pemerintahan yang buruk yang menyebabkan inefisiensi dan inefektivitas dalam pelayanan publik, meluasnya korupsi, dan rendahnya jaminan sosial terhadap masyarakat. ${ }^{20}$ Berdasarkan indikator-indikator ini, maka paling tidak hal ini dapat menolong gereja menyusun suatu perencanaan awal yang nyata dan tepat guna dalam melakukan pelayanan diakonia mereka ditengah masyarakat.

${ }^{20}$ Elia Dian, Macam-macam Kriteria Kemiskinan, diakses dari http://eliadian.blogspot.com/2013/03/macam-macam-kriteria-kemiskinan.html. 


\section{DIAKONIA GEREJA \\ DALAM DINAMIKA MASYARAKAT INDONESIA HARI INI}

Berhadapan dengan realita diatas dan juga sikap kepedulian gereja terhadap tindakan keadilan bagi dunia ciptaan, maka tindakan diakonal gereja hari ini sangat mendesak dan perlu direalisasi segera. Perealisasian ini dapat diwujudkan dalam program pelayanan diakonia gereja, yang bukan hanya sekedar urusan dalam gereja lokalnya, melainkan juga program pelayanan diakonal yang dapat memberikan dampak masif terhadap masyarakat sekitarnya. Karena pelayanan ini adalah pelayanan kemurahan, maka gereja melakukannnya sebagai perwujudan tindakan ketaatannya kepada Kristus, dan bukan sebagai suatu pelayanan yang memperhitungkan untung rugi.

Berdasarkan tradisi pastoral secara historis maka pelayanan diakonia ini memang pada dasarnya berusaha menolong orang miskin untuk menemukan sumber-sumber dalam dirinya. Tindakan kemurahan dari gereja dalam bentuk diakonia ini seharusnya mempertahankan dan menjaga martabat dari sang penerima, menghormati kompetensi apapun yang mereka punya. ${ }^{21}$ Dengan perkataan lain, program penanggulangan kemiskinan berbasis pemberdayaan masyarakat menjadi praktek dari gereja yang panjang. Kepedulian Kristen terhadap orang miskin dalam cara ini memang sudah menjadi praktek gereja yang panjang namun saat ini terkikis karena formasi kebijakan ekonomi pemerintah. Misalnya di Indonesia dimana program dari pemerintah untuk penanggulangan kemiskinan yang diberikan dalam bentuk cash money (Bantuan Langsung Tunai/BLT), justru dianggap banyak orang tidak bersifat mendidik, karena hanya membuka ruang terciptanya masyarakat yang powerless. Memang tidak bisa tidak dipingkiri bahwa di satu sisi bantuan ini berarti dapat membuat dapur tetap bisa mengepul, namun disisi lain bantuan ini tidak membangun mentalitas usaha yang bertanggung jawab.

Tindakan kasih seperti ini seperti diungkapkan oleh Oden, dengan mengutip Hoppin, justru menghancurkan aktivitas diri dan energi dan tanggung jawab pribadi pada diri si miskin dan

\footnotetext{
${ }^{21}$ Apostolic Constitutions, Book II.V, diakses dari http://www.newadvent.org/fathers/07152.htm
} 
merupakan tindakan kasih yang buruk karena mensistimatisirnya ke dalam suatu sains yang membunuh semua spontanitas hati dan tindakan. ${ }^{22}$ Karena itu, ungkapan gereja mula-mula yang sangat relevan disini untuk diperhatikan adalah jikalau kemalasan adalah ibu dari kelaparan, maka gereja tidak seharusnya melakukan tindakan diakonal untuk hanya mendorong kemalasannya. Jangan menolong mereka yang malas karena hal ini justru akan menuntun si pemalas kepada demoralisasi.

Langkah konkret program gereja yang dapat dilakukan adalah pertama-tama menetapkan tindakan kasih gereja di dalam dan di luar gereja. Khusus di luar gereja, hal penting yang perlu dilakukan adalah menetapkan siapa yang akan ditolong dengan memperhatikan beberapa indikator diatas. Prinsip pertama yang secara umum dipraktekkan dalam sejarah gereja adalah memperhatikan orang yang terdekat yang sangat membutuhkan. Martin Bucer, sebagaimana dikutip Oden, menegaskan prinsip kepada siapa tindakan ini dapat dilakukan yaitu yang pertama kepada keluarga entah itu karena relasi darah, pernikahan atau karena relasi yang lain.

Bagi Bucer, jikalau keluarga sendiri sudah dapat melakukan tanggung jawabnya dengan baik ke dalam keluarganya dalam relasi ikatan dekat itu, maka gereja memiliki sumber-sumber yang lebih untuk menolong mereka yang tidak memiliki rumah dan keluarga. Karena itu dalam hal ini gereja harus mengajarkan perihal tanggung jawab mereka dalam kaitan dengan orang miskin dan tidak beruntung yang ada diantara keluarga mereka. Prinsip kedua yang Bucer paparkan adalah menolong mereka yang tidak memiliki bantuan keluarga, khususnya yang dekat dengan gereja lokal dan kemudian menyebar kepada masyarakat luas dan antar negara. Dalam hal ini kemurahan Allah harus dbagikan kepada semua tanpa diskriminasi atas dasar suku, gender, klan, dan nasionalitas. Kemurahan ini harus terpenetrasi secara universal kepada mereka yang membutuhkan. Sebagaimana Cyprianus sang Bapa Gereja mengatakan, seperti yang dikutip oleh Oden.

Sebagaimana dikatakan di atas bahwa BLT pun juga tidak dapat menyelesaikan masalah kemiskinan di Indonesia, namun

22 Thomas C. Oden, Pastoral theology: Essentials of Ministry, 277. 
dalam tahap tertentu bantuan yang bersifat finansial dan materiil ini masih dapat menolong mereka yang miskin. Namun hendaknya bantuan itu tidak berhenti sampai disana, namun perlu juga bantuan diberikan dalam bentuk benda, yang dapat dipakai untuk berusaha dan bantuan lain dapat diberikan dalam bentuk asistensi dalam rangka pelatihan keterampilan dalam bekerja. ${ }^{23}$

Di sisi lain, dengan memperhatikan indikator kemiskinan diatas maka program pelayanan diakonal gereja dapat dilakukan dalam hal pengadaan bantuan bagi ibu hamil dan anak yang dalam kondisi miskin guna perbaikan gizi. Di lain pihak program pelayanan gereja dapat ditujukan kepada dukungan finansial di bidang pendidikan agar anak-anak Indonesia memiliki kesempatan untuk mengecap pendidikan yang baik, khususnya program beasiswa gereja yang tidak terbatas kepada anak-anak didalam gereja namun di luar gereja pun. Hal ini dapat gereja lakukan dengan memperhatikan sekolah-sekolah yang notabene tidak berasal dari orang percaya saja tetapi juga berasal dari mereka yang non Kristen.

Prinsip gereja dalam mengimplementasikan tindakan kepedulian ini yang sangat penting adalah konsistensi, dimana gereja seharusnya menjadi teladan dari melakukan tindakan kebajikan; kedua adalah adaptabilitas di mana gereja menyadari bahwa bisa jadi ada program yang tidak cocok untuk area yang lain dan juga bersifat fleksibilitas dimana program yang sudah diadopsi juga dapat berubah sesuai dengan kebutuhan dari dunia yang berubah secara dinamis. Prinsip selanjutnya adalah kasih, dimana kasih ini seharusnya meluas kepada semua orang. Kebijakan ini pertama adalah persoalan manusia bukan soal bisnis atau keuntungan atau apapun. Keadilan juga menjadi perhatian dengan sorotan kepada sikap gereja agar tidak ada kelompok atau group yang memegang kuasa untuk mengeksploitasi orang lain ${ }^{24}$. Program di sisi ini adalah pengembangan mediasi gereja dalam hal nasehat hukum dan sikap kritis gereja terhadap persoalanpersoalan keadilan di negeri ini yang tergerus karena monopoli kekuasaan.

\footnotetext{
${ }^{23}$ Noordegraaf, Teologi dalam Perspektif Reformasi: Orientasi Diakonia Gereja, 247, 256.

${ }^{24}$ David O. Moberg, Inasmuch: Christian Social Responsibility in 20th Century America, 87-91.
} 
Selanjutnya hal yang sangat penting untuk dilakukan adalah penetapan strategi. Sketsa strategis ini diawali dengan menspesifikasikan tujuan dan sasaran dari program tersebut. Eksplorasi fakta melalui wawancara, questionaire, diskusi kelompok, dan analisa-analisa yang dilakukan yang dapat menolong untuk menemukan persoalan yang ada. Menemukan kebutuhan dalam masyarakat, secara khusus jikalau kebutuhan tersebut melampaui dari kebutuhan yang ditetapkan dalam program, maka tujuan itu dapat direvisi. Hal-hal penting yang dapat dilakukan dalam hal ini adalah selanjutnya menyusun pertanyaan-pertanyaan mengapa melakukan hal ini? Apa yang akan dilakukan? Siapa yang melakukan ini, kepada siapa program ini dilakukan, bagaimana kita melayani mereka, darimana dana yang dibutuhkan, siapa yang menjadi mitra pelayanannya? Dan akibat apakah yang dapat diperoleh dari program pelayanan ini?

Berkaitan dengan mitra pelayanan ini, maka sangat penting juga memilih secara selektif siapa yang menjadi rekanan pelayanan ini. Dalam kehidupan masyarakat yang semakin sekuler hari ini, maka memang alangkah baiknya kita dapat membangun kerjasama dengan berbagai macam organisasi kesejahteraan diantara gereja-gereja yang sudah memulai hal ini, jikalau cakupannya itu bersifat kemasyarakatan. Hal ini bertujuan agar kekhususan dari diakonia dalam pekerjaan ini dapat memperoleh bentuk. Namun disisi lain, betapa sensitifnya isu kristenisasi di Indonesia, maka gereja pun dalam pengembangan pelayanan diakonal kemasyarakatannya juga dapat membangun kerjasama dengan instansi-instansi pemerintah, dan dinas-dinas sosial. ${ }^{25}$ Kerjasama ini juga harus memperhatikan supervisi, akuntabilitas dan transparansi yang jelas agar kepedulian sosial gereja memang mencapai sasaran yang dimaksudkan.

Dalam Sidang Dewan Gereja Dunia di Colombo, Sri Lanka juga diberikan langkah-langkah partisipatif gereja dalam mengimplementasikan tindakan kepedulian sosial mereka, yang dapat juga menjadikan input bagi gereja dalam membangun jejaring pelayanan diakonal mereka. Dorongan yang diberikan dalam persidangan ini adalah agar gereja, para mitra ekumenis dan

\footnotetext{
${ }^{25}$ Noordegraaf, Teologi dalam Perspektif Reformasi: Orientasi Diakonia Gereja, 215-216.
} 
DGD terus membangun jejaring di antara denominasi untuk bekerja bersama dan menambah nilai dari tindakan diakonal gereja dalam konteks perkembangan yang sangat cepat. Dalam kaitan ini, pelayanan pengembangan dari diakonia gereja dalam masyarakat dapat dilakukan dengan membangun kerjasamanya dengan gereja-gereja misalnya yang sudah mengembangkan pelayanan diakonia yang berkeadilan dengan pelatihan kader kesehatan desa untuk membantu pengobatan dan penyuluhan di daerahdaerah yang tidak tersentuh pelayanan Puskesmas. Atau bisa juga dapat dilaksanakan dalam bentuk revitalisasi penanaman, dengan membantu memberikan bibit bagi masyarakat; melaksanakan perbaikan kualitas pendidikan, dengan membuat sekolah pertukangan, pertanian dan meningkatkan profesionalitas yayasan-yayasan pendidikan yang ada. ${ }^{26}$ Bahkan apa yang sudah dilakukan oleh organisasi-organisasi ini dapat menjadi inspirasi bagi gereja dalam mengembangkan pelayanan diakonia mereka yang transformatif, preventif, kuratif dan reformatif. Gereja juga diharapkan dapat memberikan respon bersama dalam membangun masyarakat yang berkeadaban bersama dengan para penganut agama lain.

Pemantapan dari tujuan dan sasaran ini kemudian mengarah kepada perencanaan ke dalam suatu program khusus. Pelaksanaan program juga tidak terlepas nantinya dengan evaluasi pelaksanaan agar modifikasi pelaksanaan menjadi lebih baik. Berkaitan dengan pelaksanaan di atas maka diharapkan para diaken sebagai pelaksana langsung mengetahui mengenai kebutuhan-kebutuhan pastoral di sekitarnya. Pemahaman mengenai diakonia secara tradisional, seperti perhatian kepada orang sakit, pelayanan kasih dan perhatian kepada orang miskin sekarang berkembang kepada pelayanan keadilan. Justitia, keadilan, dan benar adalah suatu istilah favorit yang Calvin gunakan selain caritas untuk meringkas pemikiran pada bagian kedua dari sepuluh hukum, kasih kepada sesama. Dalam Institutes-nya Calvin menegaskan bahwa pelayanan menuju keadilan adalah pelayanan kepada Allah. ${ }^{27}$

\footnotetext{
${ }^{26}$ Institut Leimena, Inpirasi dari Gereja-gereja yang Telah Bertindak Nyata untuk Mengatasi Kemiskinan, diakses dari http://www.leimena.org/en/page/v/336/inspirasi-dari-gereja-gereja-yang-telahbertindak-nyata-untuk-mengatasi-kemiskinan.

27 John Calvin, Institutes III.viii.7
} 
Usaha menemukan kebutuhan dalam gereja dan masyarakat ini memang bukan hanya tugas dari para diaken saja. Menurut Beals, tugas ini merupakan suatu komitmen semua warga jemaat kepada Kabar Baik dalam Yesus Kristus. Kabar baik tersebut adalah suatu kesaksian dari kuasa Yesus yang memulihkan, dimana orang miskin dapat melihat, menyentuh, merasakan, dan mendengar kehadiran dan kuasa dari Kristus yang hidup itu. ${ }^{28} \mathrm{Jadi}$ semua anggota jemaat sudah seharusnya bertanggung jawab untuk melakukan komitmen kepedulian ini. Karena pelaksanaan dari kepedulian ini sangat strategis, maka anggota jemaat gereja lokal dapat melakukan usaha ini secara komunal dalam gereja dengan menolong para diaken melalui memberikan informasi dan langkah bantuan nyata untuk bersama-sama dengan para diaken mewujudkan komitmen ini. Para diaken dalam hal ini juga membutuhkan bantuan jemaat untuk mempelajari persoalan yang ada dalam masyarakat. Dalam konteks ini gereja sebagai satu persekutuan orang kudus terlibat aktif dalam pelayanan kemurahan ini. Solidaritas gereja kepada mereka yang miskin bukan hanya bersifat karitatif sementara melainkan bersifat sistematis dan berkesinambungan untuk memerangi kemiskinan melalui pemberdayaan masyarakat.

Melihat kemiskinan di sekitar kita, gereja harus bersedia untuk menolong dan langkah awal yang dapat dilakukan oleh gereja adalah jemaat gereja didorong untuk hidup dalam kesederhanaan, yaitu suatu gaya hidup yang menahan pembelanjaan dan konsumsi yang tidak seperlunya dan menolak segala bentuk penyia-nyiaan sumber. Gaya hidup seperti ini yang justru sangat ditekankan dalam tradisi bergereja dalam Gereja Reformed. ${ }^{29}$ Penekanan gaya hidup macam ini merupakan perwujudan dari rasa solidaritas gereja kepada orang-orang miskin, yang justru masih belum terentaskan di Indonesia hingga hari ini dan juga sebagai suatu sikap gereja untuk menolong mereka yang membutuhkan. Kesederhanaan itu berarti pula gereja siap untuk melakukan kritik internal secara terus menerus terhadap berbagai macam aktivitas dan pelayanannya yang hanya menonjolkan kemeriahan, namun tidak memiliki dampak kepada perubahan

\footnotetext{
${ }^{28}$ Art Beals, Beyond Hunger: A Biblical Mandate for Social Responsibility, (Portland: Multnomah Press, 1978), 199.

29 John H. Leith, Introduction to the Reformed Tradition, (Atlanta: John Know, 1981), 87.
} 
sikap dan sensivitas jemaat terhadap berbagai persoalan kemiskinan di masyarakat. Dalam mengatasi persoalan kemiskinan yang sedemikian kompleks dan besar, maka gereja perlu secara proaktif dan rendah diri bersedia bekerja sama dengan umat beragama lainnya untuk menanggulangi kemiskinan, seperti yang sudah dikumandangkan oleh para partisipan dalam sidang DGD di Colombo, Sri Lanka.

Hal ini penting agar kehadiran gereja yang menjunjung harkat dan martabat manusia tanpa membedakan suku, agama dan ras menjadi nyata. Inilah panggilan gereja yang utama. Namun di saat yang sama, gereja juga perlu terus menerus menyuarakan kritik profetisnya tanpa pandang bulu terhadap berbagai macam penyalahgunaan kekuasaan, terjadinya ketidakadilan, terampasnya hak-hak masyarakat, dan terhadap sistim yang menindas dan memiskinkan manusia. Spiritualitas hidup jemaat juga harus sampai kepada sebuah kesalehan sosial, dimana energi spiritual yang dimiliki jemaat mampu untuk mendorong kepedulian jemaat akan berbagai persoalan kehidupan masyarakat. ${ }^{30}$ Spiritualitas seperti inilah yang harus menjadi perhatian gereja dalam membangun kehidupan jemaat. Itulah yang digumulkan terus dalam perkawinan sejati antara pietas dan caritas.

\section{KESIMPULAN}

Pietas dan Caritas adalah jiwa yang tidak terpisahkan dalam kehidupan ibadah kristiani. Pietas dan caritas terimplementasi dalam pelayan diakonia gereja yang bukan hanya merangkul saudara-saudara seiman, melainkan masyarakat yang ada disekitarnya. Angka kemiskinan yang tinggi di Indonesia menjadi suatu pukulan telak bagi gereja untuk berani kembali mengevaluasi pelayanan diakonianya, yang hanya bersifat ekslusif tanpa pernah menyadari bahwa pelayanan diakonia juga merupakan pelayanan kemurahan Allah kepada orang berdosa tanpa memandang dari mana si pendosa berasal.

Pelayanan kemurahan ini adalah panggilan Allah kepada gereja untuk membangun perdamaian dan persaudaraan dengan

\footnotetext{
${ }^{30}$ Sigit B. Darmawan, Kemiskinan, Pemiskinan, Dan Peran Jemaat, diakses dari http://esbede.wordpress.com/2008/07/14/175/
} 
sesama manusia, mewujudkan keadilan sosial dan perwujudan Kerajaan Allah, serta upaya membangun kemanusiaan dan kesejahteraan bagi semua. Pelayanan ini bukan hanya sekedar bersifat pelayanan kasih biasa namun juga mencakup pelayanan keadilan agar faktor-faktor yang menyebabkan kemiskinan dan pemiskinan dapat diminimalisir hingga level terendah dan kehidupan yang berkeadilan dapat dirasakan oleh semua orang.

\section{DAFTAR KEPUSTAKAAN}

Abineno, J.L. Ch., Diaken, Diakonia dan Diakonat Gereja (Jakarta: BPK Gunung Mulia, 2008)

Apostolic Constitutions, Book II.V. Diakses dari http://www.newadvent.org/fathers/07152.htm

Beals, Art. Beyond Hunger: A Biblical Mandate for Social Responsibility (Portland: Multnomah Press, 1978)

Brownlee, Malcolm, Tugas Manusia dalam Dunia Milik Tuhan: Dasar Teologis Bagi Pekerjaan Orang Kristen Dalam Masyarakat. (Jakarta: BPK Gunung Mulia, 1987)

Calvin, John, Institutes of the Christian Religion. John T. McNeill, ed., trans. Ford Lewis Battles. (Philadelphia: Westminster John Knox Press, 1975)

Darmawan, Sigit B. Kemiskinan, Pemiskinan, Dan Peran Jemaat. Diakses dari http://esbede.wordpress.com/2008/07/14/175/

Dian, Elia., Macam-macam Kriteria Kemiskinan. Diakses dari http://eliadian.blogspot.com/2013/03/macam-macam-kriteriakemiskinan.html

Forbes Jr, James A, "The Stake of the Church in Social Movement," Christianity and the Social Crisis in the 21 Century, ed. by Paul Raushenbush (Harper Collins: e-books)

Hellwig, Monika K. The Eucharist and the Hunger of the World (Kansas: Sheed and Ward, 1992) 
Institut Leimena, Inpirasi dari Gereja-gereja yang Telah Bertindak Nyata untuk Mengatasi Kemiskinan. Diakses dari http://www.leimena.org/en/page/v/336/inspirasi-dari-gerejagereja-yang-telah-bertindak-nyata-untuk-mengatasikemiskinan

Koentjaranigrat.,Manusia dan Kebudayaan di Indonesia (Jakarta: Djambatan, 1979)

Leith, John H., Introduction to the Reformed Tradition (Atlanta: John Know, 1981)

Margareta Engge Kharismawati, Penurunan Angka Kemiskinan di 2014 Sulit Tercapai. Diakses dari http://nasional.kontan.co.id/news/penurunan-angkakemiskinan-di-2014-sulit-tercapai.

McKee, Elsie Anne. Diakonia in the Classical Reformed Tradition and Today (Grand Rapids: Wm B Eerdmans, 1989)

McKee, Elsie Anne, ed., John Calvin: Writings on Pastoral Piety (New York: Paulist Press, 2001)

Menko Kesra Akui Sulit Tekan Angka Kemiskinan. Diakses dari http://www.menkokesra.go.id/content/menko-kesrakemiskinan-masih-menjadi-pr-tahun-2014).

Moberg, David O., Inasmuch: Christian Social Responsibility in 20th Century America (Grand Rapids: WmB Eerdmans, 1973)

Niebuhr, H. Richard, The Responsibility of the Church for Society. Diakses dari http://www.religiononline.org/showarticle. asp?title=2731.

Noordegraaf, A., Teologi dalam Perspektif Reformasi: Orientasi Diakonia Gereja (Jakarta: BPK Gunung Mulia, 2011)

Oden, Thomas C., Pastoral theology: Essentials of Ministry. (New York: Harper and Row Pub, 1983) 
Sider, Ronald J., Rich Christians In An Age of Hunger: Moving from Affluence to Generosityy. (Dallas: Word Publishing, 1997)

Wolterstorff, Nicholas, Hearing the Call: Liturgy, Justice, Church and World (Grand Rapids: WmB Eerdmans, 2011)

World Council of Churches, Theological Perspectives on Diakonia in 21st Century. Colombo, 2012. Diakses dari http://www.oikoumene.org/en/resources/documents/wccprogrammes/unity-mission-evangelism-and-spirituality/justand-inclusive-communities/theological-perspectives-ondiakonia-in-21st-century. 